\title{
Extension of the known distribution of Aegla strinatii Türkay, 1972 and a checklist of decapod crustaceans (Aeglidae, Palaemonidae and Trichodactylidae) from the Jacupiranga State Park, South of São Paulo State, Brazil
}

Sergio Schwarz da Rocha and Sergio Luiz de Siqueira Bueno

(SSR) Universidade Federal do Recôncavo da Bahia, Rua Rui Barbosa, 710, CEP: 44380-000, Cruz das Almas, BA, Brasil. E-mail: ssrocha@ufrb.edu.br

(SLSB) Universidade de São Paulo, Rua do Matão, trav. 14, no. 101, CEP: 05508-090 São Paulo, SP, Brasil. E-mail: sbueno@ib.usp.br

\section{Abstract}

There are over 120 species of freshwater decapod crustaceans in Brazil. This paper contributes to the knowledge of the species richness and distribution of decapod crustaceans from Jacupiranga State Park, South of São Paulo State. The main objectives were to investigate the geographical distribution of $A$. strinatii and to generate a checklist of the decapod species collected from the sampling sites. Sixteen sampling sites were investigated during the year of 2007 and four species were collected. The present report represents a new record of $A$. strinatii from São Paulo State and adds three more localities at Jacupiranga State Park where the occurrence of T. fluviatilis is confirmed.

Key words: Crustacea, Decapoda, Ribeira do Iguape, São Paulo

\section{Introduction}

Freshwater decapod crustaceans constitute a group of macroinvertebrates of high ecological and economic importance (Magalhães, 1999; Almeida et al., 2008). Recently, Almeida et al. (2008) reported 117 described species of freshwater decapods registered from Brazil. Considering some new species recently described in the families Aeglidae Dana, 1852 (Santos et al., 2009; 2010; Bond-Buckup et al., 2010a, b) and Pseudothelphusidae Ortmann, 1893 (Magalhães, 2010; Magalhães and Türkay, 2010) and the first record of Macrobracium aracamuni Rodríguez, 1982 from Brazilian territory (Mantelatto et al., 2008) this number to the present has certainly exceeded 120 species.

In the past decade, knowledge on the species richness and distribution of freshwater decapod crustaceans in the State of São Paulo have increased substantially and was investigated by Melo (2003), Rocha and Bueno (2004), Magalhães et al. (2005), Mossolin and Mantelatto (2008) and Mossolin et al. (2010). Therefore, the freshwater decapod fauna in the State of São Paulo is well known when compared to other Brazilian regions, especially after the collections for inventorying the carcinofauna conducted as part of the BIOTAFAPESP Program (Magalhães et al., 2005). 
Among families of freshwater decapod reported from the State of Sáo Paulo (see Melo, 2003 for review), Aeglidae, Palaemonidae Rafinesque, 1815 and Trichodactylidae H. Milne Edwards, 1853 stand out due to their great diversity and wide distribution throughout this State (Magalhães, 1999; Rocha and Bueno, 2004, Mossolin and Mantelatto, 2008; Mossolin et al., 2010).

The family Aeglidae has approximately 70 freshwater species endemic to temperate and subtropical regions of continental South America (Schmitt, 1942; Bond-Buckup and Buckup, 1994; Santos et al., 2009; 2010; BondBuckup, 2003; Bond-Buckup et al., 2010a, b). Currently, ten aeglid species have been reported from the State of São Paulo (Rocha and Bueno, 2004) where some of them show high endemism, and inhabit karstic regions, as in the Ribeira do Iguape River Basin (Rocha et al., 2010).

Palaemonidae is the most abundant family of freshwater prawns in Brazilian continental waters (Sampaio et al., 2009). Among all five genera within this family Macrobrachium Bate, 1868 is the most representative with 17 species reported from Brazilian territory (Pileggi and Mantelatto, 2010; Mossolin et al., 2010). Currently, 10 of these species are recorded from the State of São Paulo (Melo, 2003; Pileggi and Mantelatto, 2010).

The family Trichodactylidae is considered one of the eight exclusively freshwater crab families with 51 species distributed through Mexico, Central and South America (Yeo et al., 2008). The genus Trichodactylus Latreille, 1828 is represented in Brazil by nine species, of which four occur in the state of Sáo Paulo (Magalhães, 2003, Mossolin and Mantelatto, 2008).

In this study, we present the results of the faunal survey of the freshwater decapod from Jacupiranga State Park, South of São Paulo State. The main objectives were to investigate the geographical distribution of $A$. strinatii Türkay, 1972 and to generate a checklist of the decapod species from the streams and rivers investigated.
Materials and Methods

Fieldwork was carried out at the Jacupiranga State Park, São Paulo State, and some adjacent areas during the year of 2007. The Jacupiranga State Park is considered the second largest protected area in the State, with 150,000 acres. The hydrography of the region varies from rivers headwaters, waterfalls, fastflowing mountain streams to lowland rivers (Clauset, 1999).

The coordinates of each sampling site were recorded accurately using a GPS (Global Positioning System). All decapod specimens sampled in this survey were identified according to Melo (2003) and Bond-Buckup and Buckup (1994). Voucher materials from this study were deposited at the Museu de Zoologia (MZUSP), University of São Paulo.

\section{Results and Discussion}

Sixteen sampling sites were investigated and the results of this survey are showed in Table I. Decapod species collected were Aegla strinatii, Macrobrachium potiuna (Müller, 1880), Macrobrachium olfersi (Wiegmann, 1836) and Trichodactylus fluviatilis Latreille, 1828

Specimens of $A$. strinatii were sampled in only two locations: the Ostras stream and the Rolado Cave System. This species has up to now been reported from its type locality (Ostras stream, Tapagem Cave - also known as Devil's Cave) (Türkay, 1972; Rocha and Bueno, 2004) and the River Ribeira de Iguape (Bond-Buckup and Buckup, 1994). Thus, the present report represents a new record of $A$. strinatii from São Paulo State. The species is troglophile, that is, self-sustained populations are found inside and outside caves, with free transit between both environments (Rocha and Bueno, 2004; Rocha et al., 2010). However, it is important to emphasize that no specimens of $A$. strinatti were found in the Ostras stream after its resurgence from Tapagem Cave (Table I). Dra. Georgina Bond-Buckup also found 
no aeglids when sampling in this same locality on 21/oct/2000 (Bond-Buckup, G.: personal communication). Therefore, Tapagem Cave which is the second largest cave in São Paulo State, with 6,237 meters, may represent an obstacle that limits the distribution of $A$. strinatii downstream Ostras stream. Further investigations and surveys inside Tapagem Cave are necessary to elucidate the extent of occurrence of the species inside the cave and the existence of geographical barriers.

Specimens of T. Aluviatilis were found in 7 of the 16 sampling sites (Tab. 1). The presence of $T$. Aluviatilis at Jacupiranga State Park was already reported by Rocha and Bueno (2004) from Ostras stream and Tapagem Cave. Thus, the present study adds three more localities (Tab. 1) where the occurrence of this species is confirmed.

According to Magalhães (2003) trichodactylid crabs inhabit coastal-plain Rivers at altitudes up to 300 meters. However, specimens of T. Aluviatilis have been collected at altitudes up to 960 meters (Rocha and Bueno, 2004; Gomides et al., 2006; Mossolin and Mantelatto, 2008; present study). The ability to complete their life cycle independently of the marine environment (direct development) is an important advantage in the conquest of continental waters and river headwaters located at high altitudes of inland habitats (Rocha and Bueno, 2004).

Macrobrachium olfersii was captured at only 1 site while $M$. potiuna was collected at 7 sites. The limited distribution of $M$. olfersii may be related to its type of larval development, in which larvae is dependent of estuarine waters to complete their development (Rocha and Bueno, 2004). On the other hand, M. potiuna, which is considered a continental species, physiologically independent of estuarine water, can colonize greater number of inland environments.

Table 1. Decapod crustaceans sampled during the assessment carried out at the Jacupiranga State Park and adjacent areas. (*) inside Jacupiranga State Park borders; ${ }^{(*)}$ ) outside Jacupiranga State Park borders.

\begin{tabular}{|c|c|c|}
\hline Sampling site & Geographical coordinates & Species \\
\hline $\begin{array}{l}\text { Ostras stream (site } 1)^{*} \\
\text { (Tapagem Cave entrance) }\end{array}$ & $24^{\circ} 38^{\prime} 16.2^{\prime \prime S}-48^{\circ} 24^{\prime} 05.2^{\prime \prime W}$ & $\begin{array}{l}\text { Aegla strinatii } \\
\text { Macrobrachium potiuna } \\
\text { Trichodactylus fluviatilis }\end{array}$ \\
\hline Ostras stream (site 2$)^{*}$ & $24^{\circ} 38^{\prime} 34,1^{\prime \prime S}-48^{\circ} 23^{\prime} 43,5^{\prime \prime} \mathrm{W}$ & A. strinatii \\
\hline $\begin{array}{l}\text { Ostras stream (site } 3)^{*} \\
\text { (resurgence of Tapagem Cave) }\end{array}$ & No coordinates available & $\begin{array}{l}\text { M. potiuna } \\
\text { T. fluviatilis }\end{array}$ \\
\hline $\begin{array}{l}\text { Mouth of Ostras stream (site } 4)^{*} \\
\text { (near River Ribeira de Iguape) }\end{array}$ & $24^{\circ} 36^{\prime} 01,3^{\prime \prime} \mathrm{S}-48^{\circ} 23^{\prime} 36,1^{\prime \prime} \mathrm{W}$ & $\begin{array}{l}\text { Macrobrachium olfersii } \\
\text { T. fluviatilis }\end{array}$ \\
\hline Unnamed stream \#1 (site 1$)^{*}$ & 240 38' 09”S - 48' 24’ 18”W & $\begin{array}{l}\text { M. potiuna } \\
\text { T. fluviatilis }\end{array}$ \\
\hline Unnamed stream \#1 (site 2)* & $24^{\circ} 37^{\prime} 59,2^{\prime \prime} \mathrm{S}-48^{\circ} 24^{\prime} 18,0^{\prime \prime} \mathrm{W}$ & $\begin{array}{l}\text { M. potiuna } \\
\text { T. fluviatilis }\end{array}$ \\
\hline Rolado Cave I* & $24^{\circ} 38^{\prime} 59,2^{\prime \prime} \mathrm{S}-48^{\circ} 24^{\prime} 05,4^{\prime \prime} \mathrm{W}$ & A. strinatii \\
\hline Rolado Cave II* & $24^{\circ} 38^{\prime} 59,2^{\prime \prime} \mathrm{S}-48^{\circ} 24^{\prime} 05,4^{\prime \prime} \mathrm{W}$ & A. strinatii \\
\hline Rolado Cave III* & $24^{\circ} 38^{\prime} 59,2^{\prime \prime} \mathrm{S}-48^{\circ} 24^{\prime} 05,4^{\prime \prime W}$ & A. strinatii \\
\hline Unnamed stream \#2 (site 1$)^{*}$ & $24^{\circ} 39^{\prime} 03,3^{\prime \prime} \mathrm{S}-48^{\circ} 23^{\prime} 35,0^{\prime \prime} \mathrm{W}$ & No decapod sampled \\
\hline Unnamed stream \#2 (site 2$)^{*}$ & 240 38' 59, '” & No decapod sampled \\
\hline River Arivá* & 24o 38' 09,4”S - 48'24’33,3”W & $\begin{array}{l}\text { M. potiuna } \\
\text { T. fluviatilis }\end{array}$ \\
\hline Unnamed stream \#3* & $24^{\circ} 38^{\prime} 22,8^{\prime \prime} \mathrm{S}-48^{\circ} 24^{\prime} 39,9^{\prime \prime} \mathrm{W}$ & $\begin{array}{l}\text { M. potiuna } \\
\text { T. fluviatilis }\end{array}$ \\
\hline Frias Cave* & No coordinates available & $M \cdot$ potiuna \\
\hline Sapatu Waterfall ** & $24^{\circ} 36^{\prime} 05,0^{\prime \prime} \mathrm{S}-48^{\circ} 21^{\prime} 31,3^{\prime \prime} \mathrm{W}$ & No decapod sampled \\
\hline River Nhunguara** $^{* *}$ & $24^{\circ} 35^{\prime} 24,6^{\prime \prime} \mathrm{S}-48^{\circ} 25^{\prime} 58,6^{\prime \prime} \mathrm{W}$ & No decapod sampled \\
\hline
\end{tabular}




\section{Acknowledgements}

The authors would like to express their sincere thankfulness to Dr. Fábio Kiyohara and Dr. Emerson Contreira Mossolin for his help in sampling the specimens. We are also much grateful for the financial support provided by FAPESP (BIOTA program grant no. 1998/05073-4), and research grants provided by $\mathrm{CNPq}$ (grant no. 14112/2004-9 to SSR and grant no. 302663/2009-6 to SLSB) and CAPES. Finally, we would like to acknowledge our gratitude to all the staff members at Jacupiranga State Park and Instituto Florestal, São Paulo State.

\section{References}

Almeida, A.O.A.; Coelho, P.A.; Luz, J. R.; Santos, J.T.A. and Ferraz, N.R. 2008. Decapod crustaceans in fresh waters of southeastern Bahia, Brazil. Revista de Biologia Tropical, 56(3): 1225-1254.

Bond-Buckup, G. 2003. Família Aeglidae. p. 21-116. In: Melo, G.A.S. (ed), Manual de identificação dos Crustacea Decapoda de água doce do Brasil. São Paulo, Editora Loyola.

Bond-Buckup, G. and Buckup, L. 1994. A Família Aeglidae (Crustacea, Decapoda, Anomura). Arquivos de Zoologia, 32(4): 159-346.

Bond-Buckup, G.; Jara, C.G.; Buckup, L.; Bueno, A.A.P.; Perez-Losada, M. and Crandall, K.A. 2010a. Description of a new species of Aeglidae, and new records of related species from river basins in Argentina (Crustacea, Anomura). Zootaxa, 2343: 18-30.

Bond-Buckup, G.; Jara, C.G.; Buckup, L.; Pérez-Losada, M.; Bueno, A.A.P; Krandall, K.A. and Santos, S. 2010b. New species and new records of endemic freshwater crabs from the Atlantic forest in Southern Brazil (Anomura: Aeglidae). Journal of Crustacean Biology, 30(3): 495-502.

Clauset, L.R. 1999. Paisagens Paulistas: áreas protegidas. São Paulo, Empresa das Artes.
$185 p$.

Gomides, S.C.; Novelli, I.A.; Santos, A.O.; Brugiolo, S.S.S. and Sousa, B.M. 2003. Registro de Trichodactylus fluviatilis Latreille, 1828 (Decapoda, Trichodactylidae) para o município de Juiz de Fora, MG. Resumos XXIX Semana de Biologia e XII Mostra de Produção Científica - UFJF. 42-45.

Magalhães, C. 1999. Crustáceos Decápodes. p. 127-133. In: D. Ismael; W.C. Valenti; T. Matsumura-Tundisi and O. Rocha (eds), Biodiversidade do estado de São Paulo, Brasil. Invertebrados de água doce. vol. 4. São Paulo, FAPESP.

Magalhães, C. 2003. Famílias Pseudothelfusidae, Trichodactilidae. p. 143-289. In: Melo, G.A.S. (ed.), Manual de identificação dos Crustacea Decapoda de água doce do Brasil. São Paulo, Editora Loyola.

Magalhães, C. 2010. A new species of freshwater crab of the genus Microthelphusa (Decapoda, Pseudothelphusidae) from a tepui in the Serra do Aracá, State of Amazonas, Brazil. In: Franzen, C.; de Grave, S. and Nq, P. (eds.), Studies on Malacostraca: Lipke Bijdeley Holthuis Memorial Volume. Crustaceana Monographs, 14: 453-460.

Magalhães, C.; Bueno, S.L.S.; Bond-Buckup, G. Valenti, W.C.; Silva, H.M.; Kiyohara, F.; Mossolin, E.C. and Rocha, S.S. 2005. Exotic species of freshwater decapod crustaceans in the state of Sáo Paulo, Brazil: records and possible causes of their introduction. Biodiversity and Conservation, 14: 1929-1945.

Magalhães, C. and Türkay, M. 2010. A new freshwater crab of the genus Brasiliothelphusa Magalhães and Türkay, 1986 from Rio Aripuanã, southern Amazon Region, Brazil (Decapoda: Peudothelphusidae). Nauplius, 18(2): 103-108.

Mantelatto, F.L.; Pileggi, L.G.; Suárez, H. and Magalhães, C. 2008. First record and extension of the known distribution of the inland prawn, Macrobrachium aracamuni Rodríguez, 1982 (Decapoda, Palaemonidae) in Brazil. Crustaceana, 81(2): 241-246.

Melo, G.A.S. 2003. Manual de Identificação 
dos Crustacea Decapoda de água doce do Brasil. São Paulo, Ediçóes Loyola, 429p.

Mossolin, E.C. and Mantelatto, F.L. 2008. Taxonomic and distributional results of a freshwater crab fauna survey (Family Trichodactylidae) on São Sebastião Island (Ilhabela), South Atlantic, Brazil. Acta Limnologica Brasiliensia, 20(2): 125-129.

Mossolin, E.C; Pileggi, L.G. and Mantelatto, F.L. 2010. Crustacea, Decapoda, Palaemonidae, Macrobrachium Bate, 1868, São Sebastião Island, state of São Paulo, southeastern Brazil. Check List, 6(4): 605613.

Pileggi, L.G. and Mantelatto, F.L. 2010. Molecular phylogeny of the freshwater prawn genus Macrobrachium (Decapoda, Palaemonidae), with emphasis on the relationships among selected American species. Invertebrate Systematics, 24: 194208.

Rocha, S.S. and Bueno, S.L.S. 2004. Crustáceos decápodes de água doce com ocorrência no Vale do Ribeira de Iguape e rios costeiros adjacentes, São Paulo, Brasil. Revista Brasileira de Zoologia, 21(4): 10011010.

Rocha, S.S.; Shimizu, R.M. and Bueno, S.L.S. 2010. Reproductive biology of females of Aegla strinatii (Decapoda: Anomura: Aeglidae). Journal of Crustacean Biology, 30(4): 589-596.

Sampaio, S.R.; Nagata, J.K.; Lopes, O.L. and Masunari, S. 2009. Camarôes de águas continentais (Crustacea, Caridea) da Bacia do Atlântico oriental paranaense, com chave de identificação tabular. Acta Biológica Paranaense, 38(1-2): 11-34.

Santos, S.; Bond-Buckup, G.; Pérez-Losada, M.; Bartholomei-Santos, M.L. and Buckup, L. 2009. Aegla manuinflata, a new species of freshwater anomuran (Decapoda: Anomura: Aeglidae) from Brazil, determined by morphological and molecular characters. Zootaxa, 2088: 3140.

Santos, S.; Bond-Buckup, G.; Pérez-Losada, M.; Jara, C.G.; Crandall, K.A. and Buckup, L. 2010. New records and description of a new species of Aeglidae (Crustacea: Anomura) from river basins in Southern Brazil. Nauplius, 18(1): 79-86.

Schmitt, W.L. 1942. The species of Aegla, endemic South American fresh-water Crustacean. Proceedings of the United States National Museum, 91(31-32): 431-524.

Türkay, M. 1972. Neue Höhlendekapoden aus Brasilien (Crustacea). Revue Suisse de Zoologie, 79(15): 415-418.

Yeo, D.C.J.; Ng, P.K.L.; Cumberligde, N.; Magalhães, C. Daniels, S.R. and Campos, M.R. 2008. Global diversity of crabs (Crustacea: Decapoda: Brachyura) in freshwater. Hydrobiologia, 595: 275-286. 